\title{
Pancasila's Perspective on Dichotomous View between Inspection and Public Service in Immigration Border Control
}

\author{
Agung Sulistyo Purnomo ${ }^{1 *}$, Wisnu Widayat ${ }^{2}$, Wahyu Eka Putra ${ }^{3}$ \\ 1) Immigration Polytechnic, Jl. Raya Gandul, Depok, West Java, 16514, Indonesia; ${ }^{2)} \mathrm{Jl}$. Raya Gandul, Depok, West Java, 16514 , Indonesia; ${ }^{3)} \mathrm{Jl}$. \\ Raya Gandul, Depok, West Java, 16514, Indonesia \\ ${ }^{1)}$ agungpurnomo@poltekim.ac.id, ${ }^{2)}$ wisnuwidayat@poltekim.ac.id, ${ }_{2}^{3)}$ wahyuekaputra@poltekim.ac.id \\ *Corresponding author
}

ARTICLE INFO

Article history

Received 10 July 2021

Revised 17 August 2021

Accepted 27 August 2021

Keywords

Immigration inspection;

Immigration services;

Pancasila;

TEGAS.

\begin{abstract}
This paper aims to awaken the consciousness of the government and its people towards the importance of the noble values of Pancasila to be implemented in each aspect of life in a nation-state. The dichotomous inspection and public service in Immigration Border Control has undergone inexhaustible which, eventually, putting border controllers into a dilemma when the roles and responsibilities of border control officials as a document examiner or public servant are separated. Many immigration officials in the border are losing the public service spirit and, at the same time, bringing down the sacred meaning of public service. This phenomenon has contributed to the misbehavior and bad decision making which directly impacts the society as service users. Pancasila, as Indonesian ideology, becomes the anti-thesis of positivist/modernist paradigm. It is expected that the spirit of public service by TEGAS will be an alternative solution in the midst of increasingly high public demand for a better border control management.
\end{abstract}

This is an open access article under the CC-BY-SA license

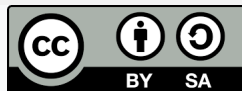

\section{Introduction}

Immigration checks/clearance at Immigration Border Control has always seized the attention of various parties, including from the community as the service users and the government (Directorate General of Immigration) as a public service provider. Various kinds of praise and complaints from the public over the performance of immigration officers at Immigration Border Control have been widely recorded by mainstream media and social media. It shows how much attention the public has towards the accountability of Immigration officers at Immigration Border Control, which also bears a moral burden for Immigration with its enormous responsibility as a state guard for the country's border gates and "storefronts" in the eyes of the world.

Related to complaints felt by the public about the performance of Immigration officers at Immigration Border Control that often occur are the behavior of officers and the length of time spent in checking travel documents (passports). The behavior of officers at Immigration Border Control that is often highlighted is because of the lack of hospitality 
and integrity in carrying out their mandate. The time for examining documents, which is considered relatively long, is due to the limited support facilities and personnel in the field. These issues are important to be comprehensively studied to get an ideal description of the "face" of immigration in Indonesia and how to achieve it.

It is still difficult to find a literature about the public complaints on public services in immigration field, especially in Immigration Border Control. Starting from this point, we try to contribute scientifically to the immigration, in form of ideas to build an authoritative and world-class Indonesia Immigration

If traced further back, it can be found that the source of the many complaints arisen in the community over the performance of Immigration officers at Immigration Border Control is due to a misperception/understanding of their status and responsibilities as a public servant. The fault in interpreting public services has an impact on the mindset of some people and the implementation of immigration tasks in the field. From the phenomenon above, there is a reduction of the meaning from the word service in the public sector and leads to a dichotomy between service and inspection at Immigration Border Control. It has led to an understanding of Immigration Border Control management such a private sector that is not citizen oriented. The result is quite serious, from the loss of the dignity as a public servant to the decline in the level of public trust in the organization. The degradation ways of thinking and performance are the main culprits of this study. This study hopes to shed light on the dismissal of dichotomous understanding between inspection and service at Immigration Border Control by using Pancasila paradigm.

\section{Method}

This research applies qualitative approach by using Pancasila paradigm to formulate a new spirit/principle on the performance of Immigration officers at immigration border of the Republic Indonesia. We need a holistic paradigm to be able to dissect counterproductive understanding. Pancasila as a paradigm inheritance of the founder of Indonesia, can equalize a variety of perspectives such as interpretivism, critical, postmodernism, and theistic spiritualism in one holistic perspective reflected in 'the five principles of Pancasila'. Pancasila paradigm, in this case, is expected to reduce the modernist/positivist way of thinking which is characterized by reductionist, dichotomist and materialist behavior [1]. Pancasila paradigm is chosen to erase fanaticism towards one paradigm to find the truth. Another purpose of this approach is to open up insights and prevent onesided justification of the paradigm adopted [2]. Therefore, this study will demonstrate some steps to understand and investigate various points of view, then draw a conclusion from the facts and further compare them with Pancasila paradigm in order to neutralize the dichotomous view between inspection and service at Immigration Border Control. The view that will be used to elaborate the values contained in the Pancasila paradigm while deconstructing the dichotomous view mentioned above is theistic-spiritualist (Islam).

The data analysis used in this study comprised a procedure of holistic method, which was the enhancement of triangulation method with an additional aspect of intuition derived from authors' deep contemplation and $d z i k r$ as the unique mediator practiced among theistic spiritualists $[3,4]$. Subsequently, interviews and observation are conducted with the immigration officials at the busiest Immigration Border Control like Soekarno-Hatta and 
Ngurah Rai airports. The last step taken is arranging seminar as well as debates and reviewing related literatures and other secondary data like official reports and letters.

The collected data were thematically analysed and interpreted under the Islamic worldview [5,6] to construct a conclusion and limitation for further area of research. The Islamic perspective is used not only because of the writers' belief, but it is also due to the lack of attention on Islamic values in the management and public policy fields. On the other hand, two other Samawi religions (Judaism and Christianity) have been widely used as tools to find the truth in the business management and ethics fields [7]. Therefore, this study is not intended to deny other beliefs as modernist mindset, but to study some perspectives to enrich the scientific realm and contribute to the establishment of Pancasila as the foundation of the official ideology of Republic of Indonesia. The diversity of demographic of Indonesia contributes to the justification of the effectiveness of this paradigm approach. Even the goal of strengthening Pancasila education itself is to shape Indonesian people who are religiously devout and pious individually, socially, and spiritually [8]. We hope that the Pancasila paradigm approach can be a solution to the problems in the academic realm in general and in the immigration field in particular.

\section{Results and Discussions}

The basic assumption of the topic is that inspection means immigration check and service mentioned above means public services, because until now there has not been found literature defining immigration services. This assumption is important to be considered because it will also determine the output and outcome of this study. For example, if one of the terms is not specific, then the comparison will certainly imbalanced. It can be seen on the number of misperceptions about service at the Directorate General of Immigration at all levels. Most of the civil apparatuses identify service as the activities that normally occur in the private sector such as the sale and purchase of goods and services. Certainly, it will reduce the meaning of service in the public sector. This is very inaccurate and far from the spirit of bureaucratic reform towards good government. Therefore, at the beginning of this study, it is very important to state explicitly, once again, that what is meant by service is public service. It is reinforced by the status of immigration officers who are also public servants so that, eventually, they must comply with laws governing public services in Indonesia related to the implementation of duties in their fields.

A misconception on the basic concept of public service is very dangerous, not only for immigration officers as service providers but also for the wider community as users. Based on the Act No. 25 of 2009 [9], "Public service is an activity or series of activities in the framework of meeting service needs in accordance with the statutory regulations for every citizen and resident of goods, services, and/or administrative services provided by public service providers". Based on this definition, it is clear that public service is not the same as private sector service which is more profit oriented [10]. In addition, all activities/operations of public service must refer to principles such as: public interest, legal certainty, equality of rights, etc. as stated in the law above.

The potential dangers arising from misinterpretation of service in the public sector include the following: 1. Disorienting the intentions in carrying out public service; 2 . Demeaning the dignity of public servants in the eyes of the community; 3 . Reducing the 
level of public trust in public service; 4. Triggering corrupt behavior in serving the public; 5. Discouraging the motivation of other public service providers.

The negative impact that must be anticipated due to the dichotomy toward the word 'inspection' and 'service' in general is the emergence of an irrational (delusional) view of the role of immigration officers as anti-critics so that they feel that they never go wrong in their duties as "the main filter" at the borders in maintaining sovereignty of the absolute state. It is proven by the emergence of resistance of most officers toward the constructive input and suggestions in serving the public according to the norms of national wisdom that has been mandated by the 1945 Constitution and the public service law. More specifically, immigration officers who are exposed to this concept are more likely to be arrogant, subjective in carrying out their duties as immigration examiners, and disregard rights of public service users. Certainly, this attitude cannot justify their status as public servants who must abide by the rule of law on a duty.

When explored further, it is probable that the beginning of the development of this dichotomous concept comes from the misinterpretation of the four functions of immigration in Indonesia, namely: 1. Immigration service; 2. Law enforcement; 3. National security; 4. Facilitator of economic development. The four functions as stipulated in the Immigration Act have long been misinterpreted by the internal actors, that ultimately have severe consequences in practice in the field, especially when making decisions.

As an effort to provide criticism, suggestions, and solutions to the phenomena in the field as described above, we utilize Pancasila as a paradigm as well as a methodology in this research. The Pancasila paradigm is not an alternative to other paradigms, but a logical consequence of the establishment of Pancasila as the view of life and the underlying principle of Indonesian state [11]. Pancasila, as a paradigm, is able to dissect a problem from the top to its roots. This study begins with a discussion of the important role and position of Pancasila paradigm among several paradigms that have been developed in the world. Furthermore, the main topic of this study will be holistically analyzed by using the five principles of Pancasila.

The positivistic paradigm in the area of public policy as reflected on the New Public Management (NPM), have long been used by decision makers in various parts of the world to improve performance in serving their communities by becoming (as if) a problem solver [12-14]. However, it creates a new problem, which is ignoring the rights of the community to participate in determining policies that will have a direct impact on their lives and wellbeing.

Another feature is the focus of organizational success which is measured to the extent of economic success such the private sector which is reduced to a unit of the currency value. In this way, performance appraisal is only based on how much budget can be saved or vice versa, how much budget can be absorbed. The benefits for many people have not yet been taken into account because they consider the community as a 'consumer', not a 'citizen' [15]. Therefore, people who are exposed to this concept whenever they hear the word 'service', the first assumption that arises is the mechanism of private sector service (between sellers and buyers). Thinking this way would lead to the assumption that inspection at Immigration Border Control is not a public service but a series of 
examination at national border crossings by immigration officers who 'may' ignore social (humanist) values and norms on behalf of the country.

When carefully examined, the positivistic paradigm as described will lead to satisfaction only at the level of material reality and ignore the non-material (spiritual) element. This paradigm fails to understanding humans as creatures that exist in these two dimensions [16], so their valence and dignity must be maintained as a form of fulfilling psychological and spiritual needs. As a result, all efforts are directed only to gain the maximum material benefit but at the expense of other people rights, without thinking about the fate, voices, and approval of the people who are directly affected by the policies made [17].

In Indonesia, this positivistic paradigm gains enough attention and developed to be used by many government agencies in the light of the New Public Management (NPM) framework. It is not surprising in the field of public agencies, when the word 'service' is uttered, the first issue that emerges in mind is the process/mechanism of work like service in the private sector such as restaurants, cafes, malls, and so on. Denhardt \& Denhardt [1820] have rejected this concept and corrected it by introducing the New Public Service (NPS) paradigm to restore the morale and dignity of public servants in the world. NPS is also able to accommodate other non-positive paradigms such as interpretivism, critical, and postmodernism which emphasize emancipatory principles and encourage constructive collaboration [18]. This illustration intrinsically asserts that public sector must not be treated the same as private sector. In Indonesia context, NPS paradigm has several things in common with Pancasila paradigm such as encouraging collaboration and cooperation.

Pancasila as the paradigm and ideological foundation of Indonesia has virtues that are not possessed by other paradigms such as positivism, interpretivism and critical, which are dominantly used in research and rationale in the realm of public administration. Pancasila paradigm is refined by reinforcing theistic-spiritualist view as the peak of humanity's consciousness and goal [11,21,22] Besides, the strength of Pancasila also lies on the philosophical system of Pancasila in the form of pyramid hierarchical with the first principle, 'Believe in the one supreme God', as the main reference of the other four principles and is the highest form of consciousness of a human being towards God, the source of life, whose power encompasses the material dimension (physical) and nonmaterial (spiritual) [8].

Thus, it is important to emphasize here that Pancasila paradigm which is theisticspiritualist, and will be used to analyze the dichotomous concept between 'service' and 'inspection' and realign the meaning of public sector service to its orientation. So it is no exaggeration if Pancasila paradigm can be further developed in subsequent research concerning management and public policy and formulation of good governance. Hopefully, this paradigm can be used as a reference to foster public awareness about the importance of affirmation to the highest reality (Divine) in realizing not only good government, but more than that, God Government.

In order to dispel the dichotomous understanding of inspection and service, we will use the precepts of Pancasila. In general, solving the problem of dichotomous understanding can be done in two ways i.e. deconstructing the old paradigm and producing 
a new instrument that is relevant to the real conditions resulting from the manifestation of the noble values of Pancasila, which will be elaborated in detail as follows.

\subsection{The first principle: 'Believe in the One Supreme God'}

This first principle confirms the characteristics of Indonesia as a religious country. This is strengthened by the historical facts stated that the Indonesian people for a long time and for generations believed in the existence of God [11]. The belief has been maintained until now with many rituals performed by Indonesian people from various religions such as Islam, Christianity, Catholicism, Hinduism, and Buddhism. Therefore, it is clearly seen that the Indonesian people believe that there is a close relationship between physical and non-physical dimensions such as the inseparable body and soul. The food quality for the body will affect mental health and vice versa. From this point, it is clear that the range of thinking of Indonesian people should follow these two interdependent dimensions.

In the light of this first principle, God is the center of everything, He is the earliest and $\mathrm{He}$ is also the last. His power encompasses everything in the universe without exception. All creatures that exist in this world are created systematically related to the process of cause and effect, with humans as the ultimate creation and manifestation of God on earth [23]. In brief, the existence of all beings in this world is due to the existence of God, which is called causa prima. By this foundation of thinking, we will be to explore from the lowest reality of materialism to the highest reality of Divine consciousness $[1,24]$. The awareness of the highest reality is transmitted by the founding fathers of Indonesia to the next generation in the form Pancasila as the ideology.

As described before that Pancasila is structured as a philosophical system known as pyramidal hierarchical in which the first principle is at the top of the pyramid which covers and animates one principle to the others [8]. Understanding the first principle will foster the awareness of the totality of servitude to God as the beginning and the end of life that has direct implications for human awareness as the servants of God on the earth. Consequently, being a servant of God means committing for maintaining life and not making destruction.

In public service context, the failure in understanding the concept will adversely affect the important purposes of serving the public, that is creating a prosperous society physically and mentally. These two material and non-material dimensions will always coexist in any discussion concerning the lives of many people. Certainly, this point of view will face head to head against the positivist paradigm, which is only concerned on the physical reality. Despite being dominant, the positivist paradigm turns out to have some limitations in terms of contextuality. Apart from physical reality, there are non-physical realities which are often overlooked in multi-disciplinary studies including immigration field. In fact, Indonesia has been awarded an invaluable asset of religiosity and spirituality of its people with the basis of Pancasila as the ideology [25]. This discussion re-empowers long-standing assets by maximizing Pancasila implementation in public service context, especially immigration field.

With full awareness towards the content of the first principle of Pancasila, it will be easy to identify the primary cause of the dichotomy of inspection and services in immigration field. As described earlier, ontologically, the misconception regarding the four functions of Indonesian immigration has led to a confusion of roles in carrying out border 
duties at Immigration Border Control. Instead of being understood as a whole, these four functions are instead divided into four parts that appear to be unrelated. The first function of immigration animates the other three functions. As a matter of fact, in this first principle, there is a spirit of integration and interdependence between science and religion. This contrasts with modernists who limit and even separate the relationship between science and religion $[5,6]$. Reading and understanding the four functions, according to the Pancasila paradigm, can be done as follows:

1. The immigration service involves and animates the functions of law enforcement, national security, and community welfare development facilitator;

2. Law enforcement based on the immigration service principle;

3. National security based on the immigration service principle;

4. Facilitator of community welfare development based on the immigration service principle.

As demonstrated, the immigration officers at immigration border will be able to identify themselves as part of something larger that is a government organization whose main task is to serve the wider community. Even higher, with an understanding of the essence of this first principle the immigration officers at Immigration Border Control will be able to reflect on themselves, not only being part of the universe, but also being part of the greatness of God who is almighty in maintaining, regulating, and covering everything. With this mindset, the separation of functions and compartments will disappear, the point of view on the meaning of 'service' becomes broad, covering the four functions above and everything (both physical and non-physical) that can be used to create the benefit for society and nature around it. This fundamental thought would later become the basis of a dignified public service civilization, which epistemologically, will be discussed in the second principle.

\subsection{The Second Principle: 'Justice and Civilized Humanity'}

The existence of positivist paradigm that has been settled and spread in both the government and the private sector organizations has produced individuals who are less sensitive to humanity. They donot care on how they should humanize human beings so that their dignities are preserved. From the public administration point of view, it can be seen from how the highest government authority assesses and evaluates public service units. Generally, in this paradigm, the performance of government agencies is always measured on how efficient and effective their performance is without regard to the aspirations and collaboration with public services users [20]. Likewise with the passport inspection at Immigration Border Control, which focuses on achieving its performance in extent to what is regulated in the guidelines for measuring the community satisfaction index [26,27]. As a result, the immigration officers in their workplaces only carry out the tasks according to regulations and hierarchy like machines. These work patterns are certainly not expected, because it refers to old paradigm which has been abandoned in the science of public administration [18,28]. In addition, it also eliminates the humanist side of officers and potentially ignores the rights of public services users during immigration inspection [29].

The negligence of the rights of public service users at Immigration Border Control possibly occur due to the lack of certainty in inspection time procedure of travel document. Those who believe that immigration checks are not part of service argues that the time 
limitation for inspection should not be there, because the immigration officer has absolute authority to accept or reject foreigners who will enter the territory of the Republic of Indonesia. Certainly, this is counterproductive with the government's agenda in bureaucratic reform [30].

By understanding the second principle, it is expected that we can provide public services in a humane way. The public services cannot and should not imitate private sector services that only focus on securing management and their owners at the expense of their employees, customers, and the wider community [31]. From this point of view, NPS is essentially coined to correct the old paradigm (the Old Public Administration and the NPM) which is considered obsolete (irrelevant) because it has the potential to scrape off the humanist side and is more oriented towards business and market mechanisms [13]. NPS offers a democratic approach in public policy formation which epistemologically requires collaboration, participation and consensus between providers and public service users. In brief, it can be emphasized that the dignity of public service user must be maintained like the service providers by nurturing productive dialogue. A good public service provider is a mediator who bridges various interests in society to achieve collective welfare [32].

The holistic understanding of the role of a public servant can also be utilized to dismiss arguments about immigration checks that are separate from the principles of public service, which manipulates the definition of Border Integrity in Annex 9 International Civil Aviation Organization as a justification. In fact, the border integrity is an affirmation of the empowerment of immigration and customs functions by a country to facilitate the management of border security which aims to serve the wider community. The same meaning is also stated in the background of the convention. More specifically, Annex 9 points 2.44 and 3.37 recommend that the total time spent on border inspection and clearance services and other formalities should not more that 60 minutes [33].

This basically amplifies the claim that the services carried out by the immigration officers at Immigration Border Control are not 'services' described by the positivist paradigm. Based on the second principle, the public services provide by the immigration officers at immigration checkpoints should be a way to regain the dignity and morale of the organization without ignoring the rights of service users as stipulated in the Public Service Act. We will then be able to realize a humanist and civilized public service.

\subsection{The Third Principle: 'The Unity of Indonesia'}

The third principle reflects the highest integrity of human being: the unity of idea, movement, and goals of Indonesian society in social, cultural, and territorial diversity based on belief or "sense" over the power of God Almighty. The quote of "Bhinneka Tunggal Ika, Tan Hana Darma Mangwra" which means unity in diversity, no ambiguous truth, confirms that absolute truth (God) unites all these differences. That awareness has been proven to sustain the integrity of the nation-state of Indonesia until now [34,35].

Therefore, God consciousness and spirit of solidarity of the founding fathers kept in this third principle must be maintained and revived within the scope of our lives according to their respective professions and responsibilities. As a public servant in charge of managing the borders, the crucial thing that must be done is to equate our mindset and belief with the essence of this third principle. Being a public servant has logical 
consequences for thinking impartially and universally in the duties and responsibilities in the field [36-38]. With this concept, the dichotomy of service and inspection at the Immigration Border Control becomes irrelevant. It is because the inspection is only a subsystem of service, and both are part of the supra-system that embodies it all, which is service to the Lord of the worlds.

The concept above is also supported by theistic-spiritualist understanding of the unity of the three elements of faith, which are believing with the heart, speaking verbally, and practicing this faith. Consequently, this concept can be implemented well in the scope of the Indonesian supra-system, then narrowed down to an organizational system, and reduced to an individual sub-system as an immigration officer. Methodologically, the three elements of faith mentioned above can be interpreted into awareness of itself as a servant of God (faith), then a servant of the community (oath), and more specifically being an immigration officer at the immigration border of the Republic of Indonesia (action).

\subsection{The fourth principle: 'The Democracy Led by Wisdom in Representative Consultation'}

This fourth principle becomes the basis of Pancasila democracy which is based on the values of wisdom (which comes from Divine awareness), the principle of kinship, and deliberation. The awareness of the essence of the fourth Principle will strengthen the relationship between Indonesian society in general and the individuals within it specifically under the auspices of Divine consciousness. This Principle reminds us to the concept of civil society upon which the Republic of Indonesia is formed, which requires all its people to obey the law regardless of ethnic, racial, religious, and group [39,40]. Hence it is clear that every citizen has the same rights and obligations in accordance with the state law. Likewise, in the process of forming regulations and decision-making, it must go through a process of deliberation to reach consensus at every level of government (national, regional, or smaller scope). With this management, every decision and regulation product issued by the state will produce better results because it involves all elements with full sincerity.

Entering into the main issue regarding the dilemma between service and inspection we should, according to the observance of the fourth principle, also refer to the applicable laws and regulations as a form of high commitment to the nation, state, and God. Therefore, a method needs to be used as a justification in rectifying an incorrect understanding of this dichotomous paradigm. In analyzing this perception, we use a normative juridical approach. It is the approach that refers to the legislation or theories and legal norms that apply in Indonesia. In this case there are three laws which become our basis, three of which are the Act Number 25 of 2009 concern to the Public Services, the Act Number 5 of 2014 concern to the State Civil Apparatus, and the Act Number 6 of 2011 concern to the Immigration.

As stated earlier, the status of the employee at the Directorate General of Immigration is a State Civil Apparatus. This is based on the Act No 5 of 2014. The State Civil Apparatus is defined as "a profession as a civil provider and a government employee with an employment agreement working for a government agency". Therefore, it is clear that the immigration officers as State Civil Apparatuses in carrying out the main tasks and responsibilities mandated by the related organization are attached to the provisions and 
norms contained in the respective regulations. Not to mention the fact that the State Civil Apparatus is a public servant.

According to article 10 of the Act No5/2014, it is stated that the State Civil Apparatus has three main functions, three of which are implementing public policies, public servants, and unifying the nation. With this law, it is clear that all state civil Apparatuses must carry out the three mandated functions. Thus, the Directorate General of Immigration employees in implementing public policies must be able to put themselves as a public servant. Both in the context of providing public services at the Immigration Office, as well as at the Immigration Border Control .

In brief, the services carried out by government agencies are different from the services performed in the private sector. Many people assume that the connotation of services provided by government agencies is similar to private sector services which refer to the concept of hospitality service. But actually public services and services in the private sector have a different orientation [41].

Table 1. The Scope of Public Services, Article 5, the Act 25/2009 [43]

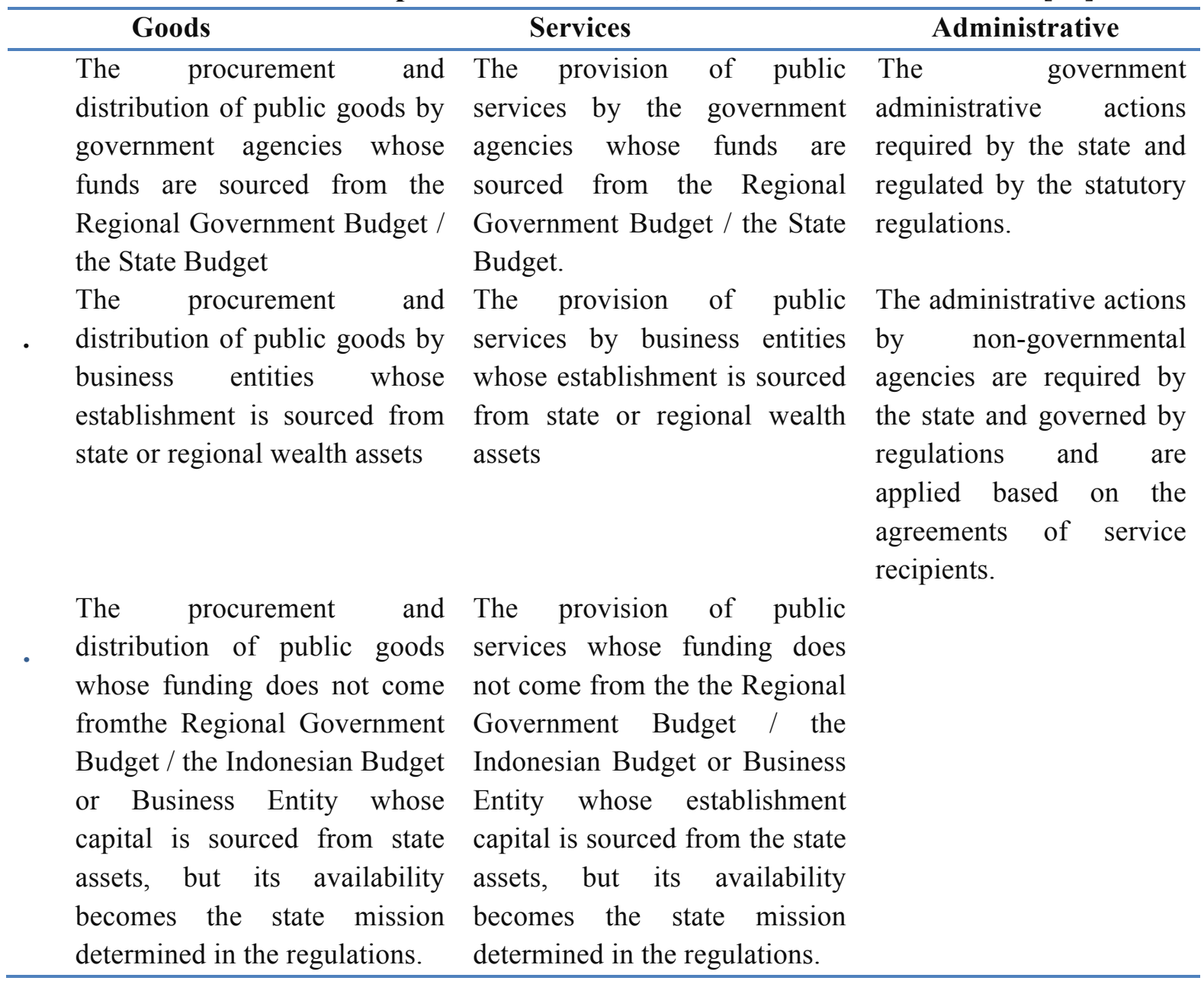

The most fundamental difference is the relationship between service providers with stakeholders or service users. In private sector services, the service providers are only focused and responsible to parties related to the services provided. It is different from the government agencies as providers of public services. In providing services, the government 
must not only pay attention to those who obtain services directly but also must pay attention to and prioritize the interests of the general public. This is appropriate with the principles of public service as regulated in Article 4 of the Act Number 25/2009. In that article, the first principle of public service is public interest. All services performed by public agencies must be able to provide added value for the society [42].

In addition, the Act No. 25/2009 also specifically regulates the public service delivery. In Article 1 Paragraph 1, it is defined that "Public service is an activity or series of activities in the context of fulfilling service needs in accordance with the laws and regulations for every citizen and resident of goods, services, and or administrative services provided by public service providers". Based on the above definition, the Act regulate the rights and obligations of public institutions as service providers and the public as service recipients. The Act of Public Services also explains the scope of the public service delivery given to the public which includes the service of goods, services and administrative services (see Table 1).

Table 1 shows that the immigration check carried out at the Immigration Border Control is also a part of the public service applied by the Directorate General of Immigration. As mandated by the Act No. 6/2011 concern to the Immigration, everyone goes in and out the Indonesian territory must go through immigration checks at the Immigration Border Control. Based on the regulation, the Directorate General of Immigration is clearly given the mandate to provide public services at immigration checkpoints. The interesting point is the public services recipients in which the service receiver is not only those who are currently travelling across the borders but also the Indonesian community in general.

In the Minister of Law and Human Rights Regulation No. 44/2015 concern to Procedures for checking in and out the Indonesian Territory at the Immigration Border Control includes procedures for Immigration officers in implementing the immigration checks. In general, for the Indonesian citizens who will go in or out the Indonesian territory will be examined through some steps such as checking travel documents, interviews, scanning travel documents, checking alert list, as well as providing the entrance/exit signs when the problem is not found. For foreigners who come to Indonesia, the inspection held through the inspection stages of travel documents, interviews, visa inspection, document scanning, biometric records, checking the list of alert, and giving admission marks. As for foreigners going out the Indonesian territory, it is held through some stages such as travel documents check, interviews, inspection of exit permits/re-entry permits, document scanning, biometric records, checking list of alert, issuing exit signs.

Based on the description above, it can be seen that the administrative services performed at the Immigration Border Control includes: providing entrance or exit signs for Indonesian Citizens and Foreign Citizens, and Granting visas on arrival and/or residence permits for Foreign Citizens. The public services Act stated that all administrative services is held by the government. The regulation also explains that the administrative action is all the services of providing documents involving the needs of the population. Based on the explanation, it is clear that the provision of entrance and exit signs and granting visas when arrival provided in the immigration inspection process can also be classified as an administrative service. 
Besides the administrative services, the public service law mentions activity services as a public service, which include the provision of health, education, traffic, justice, and security. In relation to that, the immigration regulation explains that Immigration Border Control is the place to manage the immigration function along the border of Indonesian Territory. The functions of immigration include Immigration Services, Law Enforcement, State Security, and Community Welfare Development Facilitators. Therefore, by implementing the Immigration clearance at Immigration Border Control, the Directorate General of Immigration has provided services to the Indonesian people by law enforcement and national security protection.

As mandated by the regulation, Indonesia Immigration adheres to the principle of Selective Policy in implementing Immigration checks. Only the foreigners who do not bring harm, and benefits the nation can come into Indonesian territory. By conducting immigration clearance that follows the established procedures, it is clear that the Immigration has provide public services in state security services. The services provided have a direct impact on national security and the broader community. The immigration has carried out the mandate in the preamble of the 1945 Constitution that is protecting all Indonesian people and all Indonesian homelands. We summarize public service and inspection roles of immigration in the Table 2 and Figure 1.

Table 2. Public Services in Immigration Inspection

\begin{tabular}{ll}
\hline \multicolumn{1}{c}{ Administrative Services } & \multicolumn{1}{c}{ Activity Services } \\
\hline $\begin{array}{l}\text { Providing entry and exit signs for Indonesian } \\
\text { citizens and foreigners }\end{array}$ & National Security in protecting Indonesian \\
pranting visa on arrival and residence permit for in general & Law Enforcement toward the Immigration \\
foreigners & $\begin{array}{l}\text { offenders, in order to protect Indonesian people } \\
\text { in general }\end{array}$ \\
\hline
\end{tabular}

Figure 1. Public Service Scope and its Intersection with Immigration Inspection

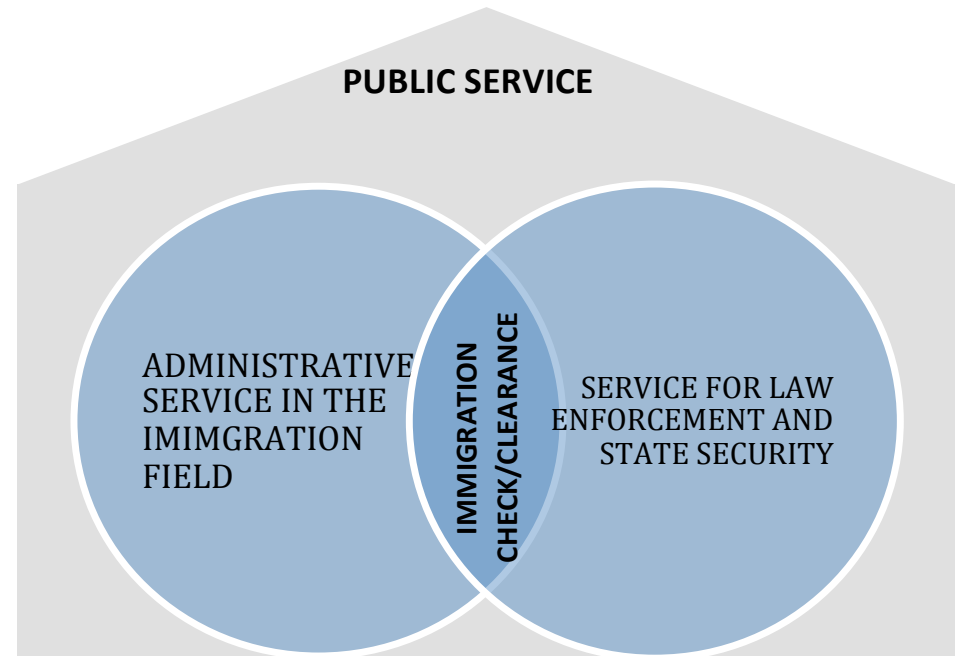

\subsection{The Fifth Principle: 'Social Justice for all of the People of Indonesia'}

After understanding the perspectives of the four principles before toward the dichotomy of service and inspection, the last principle of Pancasila paradigm is social 
justice for all Indonesian. This fifth Principle can be realized by balancing the material and spiritual needs [34][44]. This perspective requires consistency of each individual and community to actualize the God and humanity values simultaneously in life.

Justice meant here is based on the first principle that is deductive referring to the highest justice coming from the revelation, so what we need to do is understanding and implementing it in our life [45]. This concept is different from philosophical versions such as Aristotle and John Rawls which are inductive (rational) by dividing justice into three (legal, commutative, and distributive). Therefore, the spirit for implementing the two concepts above is also different. The rational justice usually only becomes a guide in social interaction. On the other hand, the revelational justice is more a demand for believers to spread the good for all humanity and nature. Furthermore, Qutb [46] and Shihab [47] also affirm that justice is firstly demanded from and towards oneself, by putting desire and anger under the light of religion but not vice versa. The justice that will be accounted for is from ourselves to the family, other people, the environment, and even to our own enemies.

In relation to the duties in Immigration Border Control, within the perspective of the five principles, the immigration officers are required to provide fair service to the public in accordance with the guidelines of their belief (divine justice). However, it is not easy to disseminate the concept above and apply them to routine tasks in the field. There are lots of questions and confusion about the possibility of implementation at Immigration Border Control. Specific 'tools' to connect between theory and practice are needed to realize the social justice for all Indonesian. In this light, we propose the principle of service "TEGAS" as a reference for Immigration officers at Immigration Border Control.

TEGAS is a manifestation of Pancasila paradigm which is an acronym for Tanpa Pamrih, Empat Fungsi Terpenuhi, Gesit, Akuntabel, Simpatik (selfless, four functions fulfilled, fast, accountable, and sympathetic). The first point, 'selfless' is the realization of the first Principle that negates the intention of an Immigration officer on duty to other than Allah SWT. The second point, 'four functions fulfilled' affirms that the public service at Immigration Border Control must fulfill all four Immigration functions as mentioned in the Immigration Act to restore the dignity of border security as mandated by the second principle. The third point is 'fast', sourced from the third principle which indicates the integrity of thoughts, words, and actions of an Immigration officer in serving the community, to be fast and responsive in responding public service users needs. The fourth point, 'accountable', is the manifestation of the fourth principle that means compliance with the laws and is ready to take responsibility for the tasks or mandates before the nation, state, and God. Finally, 'sympathetic' means very engaging, inspired by the fifth principle, becomes the media of an immigration officer to provide security and comfort to the wider community as the simplest actualization of social justice.

While it is extracted from the values and philosophy of Pancasila, it is also obligatory to use Pancasila philosophical system which is pyramidal hierarchical, where the first point is 'selfless' as the peak and the main key which cover, binds, and animates the four others. The last point, 'sympathetic' becomes the base of the pyramid which helps to strengthen the other four points.

In the routine implementation, the concept of TEGAS as values can be manifested by immigration officers at Immigration Border Control in the following forms: when a 
foreigner or the Indonesian arrives at Immigration checkpoints, the first thing that must be etched in officers mind is 'selfless'. Each officer must implement the main tasks and functions as mandated sincerely and full of responsibility without expecting any kind of reward. In addition, the process of travel documents clearance must fulfill the four functions. After the document inspection process has been completed, an Immigration officer must be 'fast', which means each officer must be quick, careful, and precise in making any decisions regarding travelers entitlement for coming or leaving Indonesia, and be responsive in solving any problems emerged in Immigration checkpoints. For example, when foreigners are not allowed to come into Indonesia, the deportation process may not be protracted so that it violates the principles of certainty and justice. The next point is 'accountability'; which means each immigration officer must carry out his duties responsibly. Every Immigration officer must not only carry out a good performance as a form of accountability to agencies and the public, and must also be able to be responsible for any decisions and actions taken before God. The last aspect that should not be forgotten when implementing the task is 'sympathetic'. Every officer should be professional, firm, polite and friendly. He/she should not complicate matters and is fair (not discriminatory). Every Immigration officer must have a compassion without losing professionalism.

\section{Conclusion}

Border Control is not a new discussion. It has long been debated, especially among the immigration officers who have served at the Immigration Border Control. Nevertheless, little has been discussed thoroughly in a scholarly manner. As it has been argued in the discussion, the misperception of the public service concept has caused various negative impacts, especially related to policy-making and the quality of public service delivery.

Using the five principles as a manifestation of the Pancasila paradigm, the paper analyses a comprehensive description of the nature and existence of Immigration officers at the Immigration Border Control, starting from the ontological, epistemological, methodological, juridical, and axiological elements. An immigration officer at the Immigration Border Control must carry out the duty appropriately with the provisions formulated by the Directorate General of Immigration as a public servant and to be responsible for the mandate in the hereafter.

To move forward towards constructive thoughts and actions, the above-mentioned dichotomous understanding needs to be dismissed by internalizing the values of Pancasila in every immigration officer as stated in each of its precepts. As a specific step for internalization, there are two things that must be done. The first is to deconstruct the dichotomous understanding between inspection and service using the perspective of the five precepts of the Pancasila paradigm. Second, develop a "TEGAS" instrument that is rich of Pancasila values in carrying out the duties and routines of Immigration officers at immigration checkpoints. It is expected that with the implementation of these values, the Directorate General of Immigration as a public organization that excels and is active towards change can be an example for the community and other agencies that friendly and sympathetic service does not necessarily deny the aspect of firmness and professionalism. On the contrary, it can strengthen the characteristics of a highly civilized public service. 


\section{References:}

[1] Triyuwono I. Akuntansi Syari'ah: Menuju Puncak Kesadaran Ketuhanan Manunggaling Kawulo-Gusti. Pidato Pengukuhan Guru Besar Akunt Syariah 2006;Universita:1-24.

[2] Triyuwono I. Akutansi Syariah: Perspektif, Metodologi, dan Teori. 2nd ed. Jakarta: PT Rajagrafindo Persada; 2015.

[3] Briando B. Prophetical Law: Membangun Hukum Berkeadilan dengan Kedamaian. J Legis Indones 2017;14:313-24.

[4] Briando B, Purnomo AS. Etika Profetik Bagi Pengelola Keuangan Negara. J Akutansi Multi Paradig 2019;10.

[5] Mahzar A. Integralisme, Sebuah Rekonstruksi Filsafat Islam. Bandung: Pustaka Perpustakaan Salman ITB; 1983.

[6] Mahzar A. Merumuskan Paradigma Sains dan Teknologi Islami: Revolusi Integralisme Islam. Jakarta: Pustaka Mizan; 2004.

[7] Dsouli O, Khan N, Kakabadse NK. Spiritual capital: The Co-Evolution of an Ethical Framework Based on Abrahamic Religious Values in the Islamic Tradition. J Manag Dev 2012;31:1058-76. doi:10.1108/02621711211281843.

[8] Kementerian Riset dan Teknologi RI. Pendidikan Pancasila Untuk Perguruan Tinggi. I. Jakarta: Direktorat Jenderal Pembelajaran dan Kemahasiswaan Kementerian Riset, Teknologi, dan Pendidikan Tinggi Republik Indonesia; 2016.

[9] Menteri Hukum dan HAM. Undang-Undang Keimigrasian. 2011.

[10] Purnomo AS. Citizen-Oriented Service Delivery and Innovation (A Case Study of Passport Office in Indonesia). J Ekon Dan Kebijak Publik 2018;9:15-27.

[11] Salampessy Z, Triyuwono I, Irianto G, Hariadi B. Pancasila Paradigm: Methodology of Wawasan Nusantara for Accounting of Pancasila. Australas Accounting, Bus Financ J 2018;12:102-15. doi:10.14453/aabfj.v12i1.7.

[12] Head BW. Three lenses of evidence-based policy. Aust J Public Adm 2008;67:1-11. doi:10.1111/j.1467-8500.2007.00564.x.

[13] Lapsley I. New Public Management: The Cruellest Invention of the Human Spirit? Abacus 2009;45:1-21. doi:10.1111/j.1467-6281.2009.00275.x.

[14] Morcol G. Positivist Beliefs among Policy Professionals: An Empirical Investigation. Policy Sci 2001;34:381-401.

[15] Aberbach JD, Christensen T. Citizens and Consumers: An NPM Dilemma. Public Manag Rev 2005;7:225-46.

[16] Wilson E. Emotions and Spirituality in Religions and Spiritual Movements. Maryland: University Press of America; 2012.

[17] Innes JE, Booher DE. Reframing public participation: strategies for the 21 st century. Plan Theory Pract 2004;5:419-36. doi:10.1080/1464935042000293170.

[18] Denhardt RB, Denhardt JV. The New Public Service: Serving Rather than Steering. Public Adm Rev 2000;60:549-59. doi:10.1111/0033-3352.00117.

[19] Denhardt J V, Denhardt RB. The New Public Service Expanded Edition Serving, not Steering. New York: M. E. Sharpe; 2007.

[20] Denhardt J V., Denhardt RB. The New Public Service Revisited. Public Adm Rev 2015;75:664-72. doi:10.1111/puar.12347.

[21] Triyuwono I. Taqwa : Deconstructing Triple Bottom Line ( TBL ) to Awake Human 's Divine Consciousness. Pertanika J Soc Sci Humanit 2016;24:89-104.

[22] Triyuwono I. Akuntansi Syariah: Perspektif, Metodologi, dan Teori. 2nd ed. Jakarta: PT. RajaGrafindo Persada; 2015.

[23] Herawati A. Concerning Ibn 'Arabi's Account of Knowlegde of God (Ma'rifa) Al Haqq. Kanz Philos A J Islam Philos Mysticism 2013. doi:10.20871/kpjipm.v3i2.49. 
[24] Briando B, Triyuwono I, Irianto G. Gurindam Etika Pengelola Keuangan Negara. J Akunt Multiparadigma 2017;8:1-17.

[25] Purwastuti LA. Pendidikan Politik Nasionalis-Religius: Suatu Strataegi Memperkokoh Kebhinekatunggalikaan Indonesia. Fondasia 2010;2.

[26] Lembaga Administrasi Negara Republik Indonesia. Pedoman Penyusunan Pelaporan Akuntabilitas Kinerja Instansi Pemerintah 2003:36.

[27] Kemenpan-RB. Pedoman Penyusunan Survei Kepuasan Masyarakat Unit Penyelenggara Pelayanan Publik. Indonesia: 2017.

[28] Kuhlmann S, Bogumil J, Grohs S. Evaluating Administrative Modernization in German Local Governments: Success or Failure of the "New Steering Model"? Public Adm Rev 2008;68:851-63. doi:10.1111/j.1540-6210.2008.00927.x.

[29] Purnomo AS. The Visa Exemption Policy Implementation on Global Mobility: A Strategy to Minimising the Risks and Maximising the Benefits of Visa Policies. J Ilm Kaji Keimigrasian 2018;1:1-12.

[30] Kementerian PANRB. Road Map Reformasi Birokrasi 2015 - 20192014.

[31] Haque MS. Reforming Public Administration in Southeast Asia: Trends and Impacts. Public Organ Rev 2004;4:361-71. doi:10.1007/s11115-004-4602-5.

[32] De Blasio E, Selva D. Why Choose Open Government? Motivations for the Adoption of Open Government Policies in Four European Countries. Poloicy Stud Organ 2016:225-47. doi:10.1002/poi3.118.

[33] ICAO. International Standards and Recommended Practices; Annex 9 to the Convention on International Civil Aviation. 15th ed. Quebec, Canada: ICAO; 2017.

[34] Ludigdo U. Memaknai Etika Profesi Akuntan Indonesia dengan Pancasila. 2012.

[35] Sitorus J, Triyuwono I, Kamayanti A. Homo Economicus vis a vis Homo Pancasilaus: A Fight against Positive Accounting Theory. Pertanika J Soc Sci Humanit 2017;25:311-20.

[36] Longo F. Quality of Governance: Impartiality Is Not Enough. Gov An Int J Policy, Adm Institutions 2008;21:191-6. doi:http://dx.doi.org/10.1111/j.14680491.2008.00392.x.

[37] Rothstein B, Teorell J. What is quality of government? A theory of impartial government institutions. Gov An Int J Policy, Adm Institutions 2008;21:165-90. doi:10.1111/j.1468-0491.2008.00391.x.

[38] Holmberg S, Rothstein B, Nasiritousi N. Quality of Government: What You Get. Annu Rev Polit Sci 2009;12:135-61. doi:10.1146/annurev-polisci-100608-104510.

[39] Khan LA. The Medina Constitution. n.d.

[40] Shomad BA. Piagam Madinah dan Resolusi Konflik. Al-AdYaN 2013;VIII:53-66.

[41] Saputri Y, Almacahyani D, Hermanto N. Karakteristik Pelayanan Publik dan Pelayanan Privat. 2013.

[42] Moore M, Khagram S. On Creating Public Value: What Business Might Learn from Government about Strategic Management. 2004.

[43] Menteri Hukum dan HAM RI. Undang-Undang Republik Indonesia Tentang Pelayanan Publik. 2009.

[44] Latif Y. Negara Paripurna. Jakarta: Gramedia; 2011.

[45] Saputra AR. Konsep Keadilan Menurut Al-Quran Dan Para Filosof. J Stud Islam Dan Sos 2012;10:99-185.

[46] Quthb S. Keadilan Sosial Dalam Islam. Bandung: Pustaka Perpustakaan Salman ITB; 1984.

[47] Shihab MQ. Wawasan Al-Quran. II. Bandung: Mizan; 2007. 